\title{
High Seroprevalence of Toxoplasma gondii in Slovenian Wild Boars (Sus scrofa)
}

\author{
Petra Bandelj ${ }^{1, *}$, Diana Žele Vengušt ${ }^{1}$, Rok Blagus ${ }^{2,3}{ }^{\oplus}$, Aleksandra Vergles Rataj ${ }^{1}$ and Branko Krt ${ }^{1}$ \\ 1 Veterinary Faculty, University of Ljubljana, Gerbičeva ulica 60, SI-1115 Ljubljana, Slovenia; \\ diana.zelevengust@vf.uni-lj.si (D.Ž.V.); aleksandra.verglesrataj@vf.uni-lj.si (A.V.R.); \\ brane.krt@vf.uni-li.si (B.K.) \\ 2 Institute for Biostatistics and Medical Informatics, University of Ljubljana, Vrazov trg 2, \\ SI-1104 Ljubljana, Slovenia; rok.blagus@mf.uni-lj.si \\ 3 Faculty of Sports, University of Ljubljana, Gortanova ulica 22, SI-1104 Ljubljana, Slovenia \\ * Correspondence: petra.bandelj@vf.uni-lj.si
}

check for updates

Citation: Bandelj, P.; Vengušt, D.Ž.; Blagus, R.; Vergles Rataj, A.; Krt, B. High Seroprevalence of Toxoplasma gondii in Slovenian Wild Boars (Sus scrofa). Animals 2021, 11, 3139. https://doi.org/10.3390/ ani11113139

Academic Editor: Rita Tinoco Torres

Received: 1 October 2021

Accepted: 1 November 2021

Published: 3 November 2021

Publisher's Note: MDPI stays neutral with regard to jurisdictional claims in published maps and institutional affiliations.

Copyright: (C) 2021 by the authors. Licensee MDPI, Basel, Switzerland. This article is an open access article distributed under the terms and conditions of the Creative Commons Attribution (CC BY) license (https:/ / creativecommons.org/licenses/by/ $4.0 /)$.
Simple Summary: Toxoplasma gondii is a parasite that can cause serious disease in humans, especially in pregnant women. This parasite is found in many animals and people can be infected by eating raw or undercooked meat. Wild boar are known to harbor this parasite; populations and habitats have increased in the past decade, as it also increased the consumption of venison. The European population of wild boar has a mean prevalence of $26 \%$. In our study, we found that the prevalence in the Slovenian wild boar population is $62 \%$, the highest in the world to date. The prevalence was influenced by age and weight, but not by gender. In conclusion, the hunting community should be made aware of the high risk of parasite exposure when dealing with wild boar meat.

\begin{abstract}
Toxoplasma gondii is a zoonotic parasite of great public health concern. Wild boars could be considered an emerging source of toxoplasmosis in humans due to the popularity of venison and their increasing population. The aim of this study was to determine the seroprevalence of $T$. gondii in the Slovenian wild boar population and evaluate risk factors for human infection. Of 353 samples, $62 \%$ were positive for T. gondii using ELISA tests. This is the highest T. gondii seroprevalence reported to date in wild boar worldwide. The increase in prevalence with increasing age $(p=0.003)$ and weight ( $p=0.002$ ) were statistically significant, whereas gender was not ( $p=0.781)$. Odds for being T. gondii-positive increased with age with the largest difference being between 2-3-year-old and 1-2-year-old animals ( $\mathrm{OR}=2.66,95 \% \mathrm{CI}$ : 1.03-6.85). Animals weighing 20-40 kg had a higher risk than animals weighing $0-20 \mathrm{~kg}(\mathrm{OR}=2.74,95 \% \mathrm{CI}$ : 1.21-6.20), whereas a further increase in the weight was not associated with increasing the odds. Due to the high Toxoplasma prevalence, the study concluded that the risk of exposure to T. gondii from handling raw or undercooked wild boar meat is high. Surveillance protocols should be established at the national level together with increased awareness within the hunting community.
\end{abstract}

Keywords: Toxoplasma gondii; wild boar; game meat; zoonosis; ELISA

\section{Introduction}

Toxoplasma gondii is the most widespread zoonotic protozoan parasite that has a wide range of warm-blooded hosts at its disposal. Sexual replication of $T$. gondii occurs in the intestine of felines, which are the end host of the protozoan parasite. Humans and most animals are considered intermediate hosts because they harbor tissue cysts containing tachyzoa [1]. It is estimated that one-third of the human population is infected with $T$. gondii [1]. Prenatal infections can lead to severe problems and even death [2], whereas postnatal toxoplasmosis, although rare, can cause eye and behavioral problems [3-8]. Humans can become infected in several ways: 1 . by ingesting oocysts shed by cats, 2 . by consuming food or water contaminated with oocysts, or 3. by consuming undercooked 
meat containing the encysted parasite [9-12]. Up to $50 \%$ of human toxoplasmosis cases are foodborne. Consumption of undercooked meat products containing T. gondii tissue cysts is the main risk factor for infection [13-15]. Although meat from domestic pigs is of greater concern [15], consumption of wild boar (Sus scrofa) meat has gained popularity [16,17]. This is mainly due to the successful spread of the species in the environment $[17,18]$ and an increase in recreational hunting $[16,17]$. Wild boar, as omnivores, can contract toxoplasmosis by consuming food or water contaminated with sporulated oocysts or by ingesting infected tissues from other intermediate hosts [19]. The global seroprevalence of T. gondii in wild boar is estimated at $23 \%$, with the highest seroprevalence being $26 \%$ and $32 \%$ in Europe and North America, respectively [17]. This high prevalence of toxoplasmosis makes wild boar a suitable biological model for the dynamic assessment of T. gondii in the environment where the wild boar population is constantly present $[17,20]$. Currently, there is no surveillance program for T. gondii-infected meat intended for human consumption [17], although the European Food Safety Authority (EFSA) has identified T. gondii as a relevant biological hazard that needs to be addressed [21]. The significant increase in the Central European wild boar population in recent years means an even greater risk of human and animal exposure to T. gondii [22].

The aim of this study was to determine the seroprevalence of $T$. gondii in the Slovenian wild boar population, to assess its role as a reservoir for human infection, and to evaluate which parameters recorded by hunters have a greater predictability value for a seropositive outcome.

\section{Materials and Methods}

\subsection{Samples}

Wild boar serum samples $(n=353)$ were collected in 2016 and 2017 from apparently healthy, free-ranging animals throughout Slovenia as part of the national surveillance program for brucellosis and African swine fever. Game wardens and hunters were asked to submit samples from animals shot during the regular annual harvest. Hunters were also instructed on procedures before sample collection and were provided with field sample kits. Shortly after death, blood samples were collected from the jugular vein or the heart. The samples were transported to the veterinary faculty at the University of Ljubljana, where the serum was obtained and stored at $-20^{\circ} \mathrm{C}$ until testing for Toxoplasma antibodies. Only animals whose harvest location, sex, age, and weight were recorded by the hunters were used for this study. The animals' weights were determined by using a scale. The age of the animals was determined by tooth eruption, replacement, and wear.

The approval of the Ethics Committee/Welfare Authority was not required, as all samples were taken postmortem.

\subsection{Methods}

\subsubsection{Serological Methods}

Two commercial test kits were used for the serological detection of T. gondii during the 2-year period. Samples from 2016 were tested with the ID Screen ${ }^{\circledR}$ Toxoplasmosis Indirect Multi-Species kit (IDVET, Montpellier, France). Samples from 2017 were tested using pigtype ${ }^{\circledR}$ Toxoplasma Ab (Qiagen, Hilden, Germany). Both ELISA kits are suitable for the detection of antibodies from wild boar serum and assays were performed according to the manufacturer's instructions. Doubtful results were considered negative.

\subsubsection{Statistical Analyses}

Data were summarized as frequencies (\%). Differences between groups (positive vs. negative) for gender (male, female), age (4 categories: 0-1 year, 1-2 years, 2-3 years, $>3$ years), weight (5 categories: $0-20 \mathrm{~kg}, 20-40 \mathrm{~kg}, 40-60 \mathrm{~kg}, 60-80 \mathrm{~kg},>80 \mathrm{~kg}$ ) and region (12 regions) (Table 1) were tested using a chi-squared test with Yates continuity correction. The multivariate analysis was performed using a binary logistic regression. Random intercept by region was included in the model to account for the potential effect of the 
region (due to the large number of regions, region was not considered as a fixed effect). Due to high collinearity between age and weight, three multivariate models were fitted: (1) model including gender, age, and weight as fixed effects and region as a random effect, (2) model excluding age, and (3) model excluding weight. Results are presented as conditional odds ratios (ORs) with corresponding 95\% confidence intervals (CIs). For all statistical analyses, effects were considered significant when the $p$-value was lower than 0.05. Statistical language $R$ (version 3.6.1) was used for the analyses (R Core Team, 2019). $\mathrm{R}$ package lme4 was used to fit the models using 10 points per axis for evaluating the Gauss-Hermite approximation to the log-likelihood.

Table 1. Seroprevalence of T. gondii in wild boar based on sex, age, weight, and region.

\begin{tabular}{|c|c|c|c|}
\hline Wild Boar & Tested Animals (\%) & T. gondii Positive (\%) & $p^{*}$ \\
\hline Gender & & & 0.781 \\
\hline male & 209 (59) & $132(63)$ & \\
\hline female & $144(41)$ & $88(61)$ & \\
\hline Age (years) & & & 0.003 \\
\hline $0-1$ & $125(35)$ & $64(51)$ & \\
\hline $1-2$ & $162(46)$ & $105(65)$ & \\
\hline $2-3$ & $35(10)$ & $29(83)$ & \\
\hline$>3$ & $31(9)$ & $22(71)$ & \\
\hline Weight (kg) & & & 0.002 \\
\hline $0-20$ & $33(9)$ & $12(36)$ & \\
\hline $20-40$ & $137(39)$ & $79(58)$ & \\
\hline $40-60$ & $99(28)$ & $66(67)$ & \\
\hline $60-80$ & $55(16)$ & $42(76)$ & \\
\hline$>80$ & $29(8)$ & $21(72)$ & \\
\hline Region & & & 0.043 \\
\hline 1 obalno kraska & $2(1)$ & $2(100)$ & \\
\hline 2 goriska & $20(6)$ & $13(65)$ & \\
\hline $\begin{array}{c}3 \text { primorsko } \\
\text { notranjska }\end{array}$ & $43(12)$ & $18(42)$ & \\
\hline 4 osrednjeslovenska & $18(5)$ & $12(67)$ & \\
\hline 5 gorenjska & 0 & 0 & \\
\hline $\begin{array}{l}6 \text { jugovzhodna } \\
\text { slovenija }\end{array}$ & $129(36)$ & $87(67)$ & \\
\hline 7 posavska & $30(8)$ & $21(70)$ & \\
\hline 8 zasavska & $12(3)$ & $8(67)$ & \\
\hline 9 savinjska & $20(6)$ & $8(40)$ & \\
\hline 10 podravska & $55(16)$ & $33(60)$ & \\
\hline 11 pomurska & $24(7)$ & $18(75)$ & \\
\hline 12 koroska & 0 & 0 & \\
\hline
\end{tabular}

Data are frequencies $(\%),{ }^{*} p$-value from a chi-squared test with continuity correction.

\section{Results}

Antibodies against T. gondii were detected in 220 of 353 (62\%; CI $0.57-0.68)$ wild boar over a 2-year period. The univariate analysis showed seroprevalence in male and female wild boar of $63 \%$ and $61 \%$, respectively, and the difference was not statistically significant $(p=0.781)$ (Table 1$)$. However, seroprevalence was significantly associated with age $(p=0.003)$, weight $(p=0.002)$ and harvest location $(p=0.043)$ (Table 1$)$. The results show an increase in prevalence from $51 \%$ in animals less than 1 year old to $83 \%$ in adult wild boar of 2-3 years old. Prevalence was $36 \%$ in animals weighing less than $20 \mathrm{~kg}$, whereas it was over 70\% in animals weighing more than $60 \mathrm{~kg}$ (Table 1). Weight and age had, adjusting for gender and region, similar predictive ability, AUC $=0.665$ and 0.641 (AUC = area under the curve), respectively (Table 2). When adjusted for gender and region, 1-2-year-old animals had higher odds to be positive for T.gondii than 0-1-year-old animals (OR $=1.69 .95 \%$ CI: 1.02-2.77). Similarly, 2-3-year-old animals had higher odds than 1-2-year-old animals ( $\mathrm{OR}=2.66,95 \% \mathrm{CI}$ : 1.03-6.85), whereas the oldest group of 
animals (more than 3 years old) had a smaller, but not statistically significant, odds than animals aged $2-3$ years (OR $=0.50,95 \%$ CI: $0.15-1.63)$.

Table 2. Risk factors for the prevalence of $T$. gondii in wild boar. The results are OR ( $95 \%$ confidence intervals) and $p$-values.

\begin{tabular}{|c|c|c|c|}
\hline Wild Boar & Model $1($ AUC $=0.664)$ & Model $2($ AUC $=0.665)$ & Model $3($ AUC = 0.641) \\
\hline Gender & $p=0.963$ & $p=0.911$ & $p=0.915$ \\
\hline male vs. female & $1.01(0.63-1.61)$ & $1.03(0.65-1.63)$ & $0.98(0.61-1.54)$ \\
\hline Age (years) & $p=0.301$ & & $p=0.004$ \\
\hline $1-2$ vs. $0-1$ & $1.24(0.70-2.19)[p=0.454]$ & / & $1.69(1.02-2.77)[p=0.038]$ \\
\hline $2-3$ vs. $1-2$ & $2.19(0.78-6.09)[p=0.132]$ & / & $2.66(1.03-6.85)[p=0.042]$ \\
\hline$>3$ vs. $2-3$ & $0.47(0.13-1.65)[p=0.238]$ & / & $0.5(0.15-1.63)[p=0.249]$ \\
\hline Weight (kg) & $p=0.094$ & $p=0.001$ & \\
\hline $20-40$ vs. $0-20$ & $2.54(1.11-5.84)[p=0.028]$ & $2.74(1.21-6.2)[p=0.015]$ & / \\
\hline $40-60$ vs. $20-40$ & $1.22(0.66-2.23)[p=0.52]$ & $1.42(0.81-2.48)[p=0.216]$ & / \\
\hline $60-80$ vs. $40-60$ & $1.41(0.61-3.24)[p=0.417]$ & $1.58(0.73-3.38)[p=0.238]$ & / \\
\hline$>80$ vs. $60-80$ & $0.76(0.24-2.36)[p=0.64]$ & $0.8(0.28-2.25)[p=0.666]$ & / \\
\hline
\end{tabular}

After adjusting for gender and region, animals weighing 20-40 kg had higher odds than animals weighing $0-20 \mathrm{~kg}(\mathrm{OR}=2.74,95 \% \mathrm{CI}$ : $1.21-6.20)$, whereas higher weight was no longer significantly associated with further increasing the odds for being T.gondiipositive $(\mathrm{OR}=1.42,95 \%$ CI: $0.81-2.48, \mathrm{OR}=1.58,95 \%$ CI: $0.73-3.37$ and $\mathrm{OR}=0.80$, $95 \%$ CI: $0.28-2.25$ for $40-60 \mathrm{~kg}$ vs. $20-40 \mathrm{~kg}, 60-80 \mathrm{~kg}$ vs. $40-60 \mathrm{~kg}$ and over $80 \mathrm{~kg}$ vs. $60-80 \mathrm{~kg}$, respectively). Due to high collinearity between age and weight $(p<0.001)$, both effects were, adjusting for gender and region, not significant when age and weight were simultaneously included in the model ( $p=0.301$ and 0.095 for age and weight, respectively) (Figure 1).

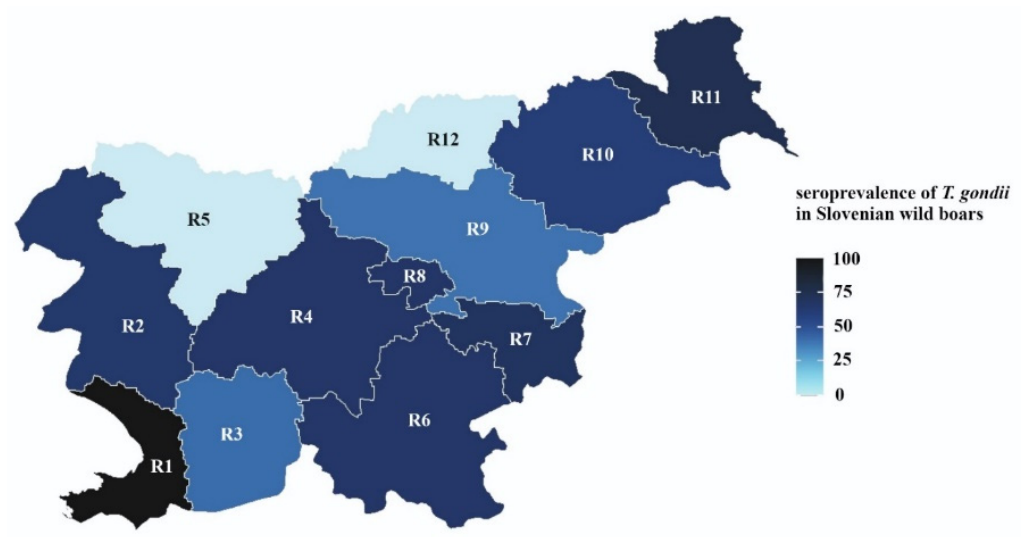

Figure 1. Seroprevalence of $T$. gondii in Slovenian wild boar (\%). Regions (R): R1—obalno kraska, R2-goriska, R3-primorsko notranjska, R4—osrednjeslovenska, R5-gorenjska, R6jugovzhodna Slovenija, R7—posavska, R8—zasavska, R9—savinjska, R10—podravska, R11— pomurska, R12-koroska.

\section{Discussion}

Wild boar meat is a potential source of T. gondii infection in humans. Due to the recent significant increase in the wild boar population in Europe and the expansion of its habitat, it poses an increasing public health concern $[13,15,17,23-25]$. This study was carried out to assess the status of $T$. gondii prevalence in the Slovenian wild boar population, to determine its potential as a reservoir for human infection, and to evaluate potential risk factors based on sex, age, weight, and harvest location. This is the first report on the seroprevalence of T. gondii in wild boar in Slovenia and the first to consider weight to assess the probability of infection. 
Samples were collected from all over Slovenia over a two-year period and tested for the presence of $T$. gondii antibodies. The overall seroprevalence was determined at $62 \%$, which is the highest worldwide seroprevalence recorded to date. Although the seroprevalence of T. gondii in the European wild boar population is estimated at $26 \%$, as noted by Rostami et al. [17], there are countries with a similarly high prevalence as in our study. Romania and Sweden have a T. gondii seroprevalence in wild boar of $57 \%$ and $50 \%$, respectively $[19,26]$. In Spain, France, the Czech Republic, and the Slovak Republic, the prevalence is around $40 \%$ [22,27-30]. The high prevalence in Slovenian wild boar is surprising. Although Slovenia $\left(46^{\circ} 8^{\prime} 57^{\prime \prime} \mathrm{N} / 14^{\circ} 59^{\prime} 34^{\prime \prime} \mathrm{E}\right)$ has an ideal Mediterranean/Continental/pre-Alpine climate that allows successful survival of $T$. gondii and wild boar $[1,17,31]$, only $55 \%$ of the territory is populated with wild boar [31]. Steep and rough terrain in mountainous regions is not an optimal habitat for wild boar [31], which explains why only a small number of animals were sampled in some regions. The results showed statistically significant differences in the prevalence of $T$. gondii due to regions, but because of too many regions combined with a low number of sampled animals in some regions, we could not estimate its effect by the model.

There was no difference between T. gondii seroprevalence in male (63\%) and female $(61 \%)$ wild boar. This is consistent with other studies showing that gender is not associated with the likelihood of infection with $T$. gondii [25,32]. In agreement with previously published studies, increasing age is also associated with a higher prevalence of Toxoplasma antibodies $[17,33,34]$. The general increase in the prevalence of $T$. gondii with age was expected: in our study, the rate ranged from $51 \%$ in the youngest group to $83 \%$ in the older group of wild boars, as animals have more opportunities to encounter the parasite over time $[17,33,34]$. Our samples from wild boar were divided into four age groups as previously reported by Gauss et al. [27], but we used the age categorization of Bier et al. [25] in the younger group ( $0-1$ year instead of $0-0.5$ years and $0.5-1$ year). Using four age groups instead of only two or three $[25,35]$ should provide a more accurate insight into the influence of age on the prevalence of T. gondii in adult wild boar (1-2, 2-3, and over 3 years old) and remain practical from the hunter's perspective. In our study, there was a significant increase in the group of 1-2-year-old and 2-3-year-old wild boar compared with the group of 0-1-year-olds and 1-2-year-olds, respectively. Interestingly, the prevalence of T. gondii reached a plateau after reaching three years of age. Regardless of the number of age groups used (2-4), some studies failed to show statistical significance of age-related seroprevalence in wild boar, although prevalence increased with age $[25,27,35,36]$. The prevalence of T. gondii in wild boar also increased with increasing weight, from $36 \%$ in animals weighing less than $20 \mathrm{~kg}$ to $76 \%$ in animals weighing $60-80 \mathrm{~kg}$. A significant increase in prevalence was observed when animals weighing 20-40 kg were compared with animals weighing less than $20 \mathrm{~kg}$, whereas further increases in weight were not associated with further increases in odds. To date, no data have been reported on the prevalence of T. gondii in relation to the weight of wild boar, which is understandable given the strong association between increasing weight and age. However, weight is accurately measured by experienced and less experienced hunters, whereas age can be less accurately determined if the hunter is not experienced. Since both parameters are usually noted by hunters, we decided to evaluate which of the two variables is a better predictor of a positive T. gondii outcome. Age and weight were evaluated together in Model 1 and separately in Models 2 (weight) and Model 3 (age). All models had similar predictive power, indicating that both variables (age and/or weight) can be used equally to estimate the risk of exposure to the parasite. To the best of the authors' knowledge, this is the first study to report weight-dependent $T$. gondii seroprevalence in wild boar.

In Slovenia, the prevalence of toxoplasmosis in women of childbearing age has decreased in recent decades, from over $50 \%$ in the 1980 s to about $25 \%$ in the new millennium [12,37]. This is probably due to improved hygiene, lower T. gondii infection in animals from intensive farming, and increased consumption of frozen meat [12]. However, the Slovenian wild boar population has increased significantly over the last decade and is 
expected to increase further as land is still available for habitat expansion [31]. The high population density of wild boar and the highest $T$. gondii seroprevalence worldwide to date means that the Slovenian wild boar population could be an important source of $T$. gondii infection in humans-particularly for those who handle and consume raw or undercooked venison, which is becoming increasingly popular [25]. The high seroprevalence does not mean that all seropositive animals are infected with tissue cysts $[25,28,38]$. A study by Richomme et al. [28] described that only half of the seropositive animals had infectious tissue cysts. If we take this information into account, the probability of becoming infected with T. gondii through handling and consuming raw wild boar meat could be one in three for people living in the territory of Slovenia. Because of the public health importance, surveillance protocols for T. gondii in wild boar and other game animals should be considered at the national level. A follow-up study with other game animals and potential $T$. gondii sources would be helpful to better determine the reasons for the high seroprevalence in the wild boar population and its dynamics in the environment.

\title{
5. Conclusions
}

The Slovenian wild boar population has the highest prevalence of $T$. gondii antibodies in the world to date. Weighing and/or accurate determination of the age of the animal may have good predictive value for $T$. gondii infection. The hunting community is at high risk of $T$. gondii infection because its members regularly handle uncooked raw wild boar meat. Therefore, additional efforts should be made to educate people in the hunting community about the impact of the parasite and its implications for its more susceptible members.

\begin{abstract}
Author Contributions: Conceptualization: B.K., A.V.R. and P.B.; Methodology: B.K. and R.B.; Software: R.B.; Validation: B.K. and R.B.; Formal Analysis: B.K. and R.B.; Investigation: A.V.R., D.Ž.V. and P.B.; Resources: B.K.; Data Curation: P.B. and D.Ž.V.; Writing-Original Draft Preparation: P.B.; Writing-Review and Editing: P.B., D.Ž.V., R.B. and B.K.; Visualization: B.K. and A.V.R.; Supervision: B.K. and A.V.R.; Project Administration: P.B. and B.K.; Funding Acquisition: B.K. All authors have read and agreed to the published version of the manuscript.
\end{abstract}

Funding: This research was funded by the Slovenian Research Agency (research core funding No. P4-0092) and by the Administration of the Republic of Slovenia for Food Safety, Veterinary Service and Plant Protection.

Data Availability Statement: The data presented in this study are available on request from the corresponding author.

Acknowledgments: The authors thank all hunters for their participation in the study by collecting the samples. We would like to thank the Administration of the Republic of Slovenia for Food Safety, Veterinary Service, and Plant Protection for conceding samples to this study from their monitoring program for brucellosis and African swine fever. We thank Alenka Magdalena Usenik for her help with sample processing, Gorazd Vengušt for his assistance with data collection and Jaka Jakob Hodnik for his help with the making of Figure 1.

Conflicts of Interest: The authors declare no conflict of interest.

\section{References}

1. Dubey, J.P. Toxoplasmosis of Animals and Humans; CRC Press: Boca Raton, FL, USA, 2016.

2. Montoya, J.G.; Liesenfeld, O. Toxoplasmosis. Lancet 2004, 363, 1965-1976. [CrossRef]

3. Logar, J.; Kraut, A.; Stirn-Kranjc, B.; Vidovic-Valentincic, N. Seroprevalence of toxoplasma antibodies among patients with ocular disease in Slovenia. J. Infect. 2003, 46, 73-74. [CrossRef]

4. Sutterland, A.L.; Fond, G.; Kuin, A.; Koeter, M.W.J.; Lutter, R.; van Gool, T.; Yolken, R.; Szoke, A.; Leboyer, M.; de Haan, L. Beyond the association. Toxoplasma gondii in schizophrenia, bipolar disorder, and addiction: Systematic review and meta-analysis. Acta Psychiatr. Scand. 2015, 132, 161-179. [CrossRef]

5. Rostami, A.; Seyyedtabaei, S.J.; Aghamolaie, S.; Behniafar, H.; Lasjerdi, Z.; Abdolrasouli, A.; Mehravar, S.; Alvarado-Esquivel, C. Seroprevalence and risk factors associated with toxoplasma gondii infection among rural communities in Northern Iran. Rev. Inst. Med. Trop. São Paulo 2016, 58, 70. [CrossRef]

6. Shiadeh, M.N.; Niyyati, M.; Fallahi, S.; Rostami, A. Human parasitic protozoan infection to infertility: A systematic review. Parasitol. Res. 2016, 115, 469-477. [CrossRef] [PubMed] 
7. Fallahi, S.; Rostami, A.; Birjandi, M.; Zebardast, N.; Kheirandish, F.; Spotin, A. Parkinson's disease and Toxoplasma gondii infection: Sero-molecular assess the possible link among patients. Acta Trop. 2017, 173, 97-101. [CrossRef] [PubMed]

8. Martinez, V.O.; de Mendonça Lima, F.W.; de Carvalho, C.F.; Menezes-Filho, J.A. Toxoplasma gondii infection and behavioral outcomes in humans: A systematic review. Parasitol. Res. 2018, 117, 3059-3065. [CrossRef]

9. Cook, A.J.C.; Gilbert, R.; Buffolano, W.; Zufferey, J.; Petersen, E.; Jenum, P.A.; Foulon, W.; Semprini, A.E.; Dunn, D.T.; Holliman, R. Sources of toxoplasma infection in pregnant women: European multicentre case-control study Commentary: Congenital toxoplasmosis-Further thought for food. BMJ 2000, 321, 142-147. [CrossRef]

10. Dubey, J.P. Sources of Toxoplasma gondii infection in pregnancy. Until rates of congenital toxoplasmosis fall, control measures are essential. BMJ 2000, 321, 127-128. [CrossRef]

11. Tenter, A.M.; Heckeroth, A.R.; Weiss, L.M. Toxoplasma gondii: From animals to humans. Int. J. Parasitol. 2000, 30, 1217-1258. [CrossRef]

12. Logar, J.; Petrovec, M.; Novak-Antolic, Z.; Premru-Srsen, T.; Cizman, M.; Arnez, M.; Kraut, A. Prevention of congenital toxoplasmosis in Slovenia by serological screening of pregnant women. Scand. J. Infect. Dis. 2002, 34, 201-204. [CrossRef] [PubMed]

13. Cenci-Goga, B.T.; Rossitto, P.V.; Sechi, P.; McCrindle, C.M.; Cullor, J.S. Toxoplasma in Animals, Food, and Humans: An Old Parasite of New Concern. Foodborne Pathog. Dis. 2011, 8, 751-762. [CrossRef]

14. van der Giessen, J.; Fonville, M.; Bouwknegt, M.; Langelaar, M.; Vollema, A. Seroprevalence of Trichinella spiralis and Toxo-plasma gondii in pigs from different housing systems in the Netherlands. Vet. Parasitol. 2007, 148, 371-374. [CrossRef] [PubMed]

15. Slany, M.; Reslová, N.; Babak, V.; Lorencova, A. Molecular characterization of Toxoplasma gondii in pork meat from different production systems in the Czech Republic. Int. J. Food Microbiol. 2016, 238, 252-255. [CrossRef]

16. Meng, X.; Lindsay, D.; Sriranganathan, N. Wild boars as sources for infectious diseases in livestock and humas. Philos. Trans. R. Soc. B Biol. Sci. 2009, 364, 2697-2707. [CrossRef] [PubMed]

17. Rostami, A.; Riahi, S.M.; Fakhri, Y.; Saber, V.; Hanifehpour, H.; Valizadeh, S.; Gholizadeh, M.; Pouya, R.H.; Gamble, H. The global seroprevalence of Toxoplasma gondii among wild boars: A systematic review and meta-analysis. Vet. Parasitol. 2017, 244, 12-20. [CrossRef] [PubMed]

18. Massei, G.; Kindberg, J.; Licoppe, A.; Gačić, D.; Šprem, N.; Kamler, J.; Baubet, E.; Hohmann, U.; Monaco, A.; Ozolinšs, J.; et al. Wild boar populations up, numbers of hunters down? A review of trends and implications for Europe. Pest Manag. Sci. 2015, 71, 492-500. [CrossRef]

19. Grema, C.; Hotea, I.; Imre, M.; Dărăbus, G.; Pascu, C.; Mariş, C.; Herman, V. Seroprevalence of toxoplasmosis and swine infuenza in wild boars. Sci. Parasitol. 2015, 16, 20-27.

20. Beral, M.; Rossi, S.; Aubert, D.; Gasqui, P.; Terrier, M.-E.; Klein, F.; Villena, I.; Abrial, D.; Gilot-Fromont, E.; Richomme, C.; et al. Environmental Factors Associated with the Seroprevalence of Toxoplasma gondii in Wild Boars (Sus scrofa), France. EcoHealth 2012, 9, 303-309. [CrossRef]

21. EFSA Panel on Biological Hazards (BIOHAZ); Koutsoumanis, K.; Allende, A.; Alvarez-Ordóñez, A.; Bolton, D.; Bover-Cid, S.; Chemaly, M.; Davies, R.; De Cesare, A.; Herman, L.; et al. Public health risks associated with food-borne parasites. EFSA J 2018, 16, 5495. [CrossRef]

22. Reiterová, K.; Špilovská, S.; Blaňarová, L.; Derdáková, M.; Čobádiová, A.; Hisira, V. Wild boar (Sus scrofa)—Reservoir host of Toxoplasma gondii, Neospora caninum and Anaplasma phagocytophilum in Slovakia. Acta Parasitol. 2016, 61, 255-260. [CrossRef] [PubMed]

23. Halsby, K.D.; Walsh, A.L.; Smith, R.; Said, B.; Kirkbride, H.; Smyth, B.; Browning, L.; Larkin, L.; Morgan, D. The Health Burden of Orphan Zoonotic Disease in the United Kingdom, 2005-2009. Zoonoses Public Health 2013, 61, 39-47. [CrossRef] [PubMed]

24. Amici, A.; Cifuni, G.F.; Contò, M.; Esposito, L.; Failla, S. Hunting area affects chemical and physical characteristics and fatty acid composition of wild boar (Sus scrofa) meat. Rend. Lincei 2015, 26, 527-534. [CrossRef]

25. Bier, N.S.; Stollberg, K.; Mayer-Scholl, A.; Johne, A.; Nöckler, K.; Richter, M. Seroprevalence of Toxoplasma gondii in wild boar and deer in Brandenburg, Germany. Zoonoses Public Health 2020, 67, 601-606. [CrossRef]

26. Wallander, C.; Frössling, J.; Vågsholm, I.; Uggla, A.; Lundén, A. Toxoplasma gondii seroprevalence in wild boars (Sus scrofa) in Sweden and evaluation of ELISA test performance. Epidemiol. Infect. 2015, 143, 1913-1921. [CrossRef]

27. Gauss, C.; Dubey, J.; Vidal, D.; Ruiz, F.; Vicente, J.; Marco, I.; Lavin, S.; Gortazar, C.; Almería, S. Seroprevalence of Toxoplasma gondii in wild pigs (Sus scrofa) from Spain. Vet. Parasitol. 2005, 131, 151-156. [CrossRef] [PubMed]

28. Richomme, C.; Afonso, E.; Tolon, V.; Ducrot, C.; Halos, L.; Alliot, A.; Perret, C.; Thomas, M.; Boireau, P.; Gilot-Fromont, E. Seroprevalence and factors associated with Toxoplasma gondii infection in wild boar (Sus scrofa) in a Mediterranean island. Epidemiol. Infect. 2010, 138, 1257-1266. [CrossRef]

29. Closa-Sebastià, F.; Casas-Díaz, E.; Cuenca, R.; Lavrin, S.; Mentaberre, G.; Marco, I. Antibodies to selected pathogens in wild boar (Sus scrofa) from Catalonia (NE Spain). Eur. J. Wildl. Res. 2011, 57, 977-981. [CrossRef]

30. Račka, K.; Bártova, E.; Budiková, M.; Vodrážka, P. Survey of Toxoplasma gondii antibodies in meat juice of wild boar (Sus scrofa) in several districts of the Czech Republic. Ann. Agric. Environ. Med. 2015, 22, 231-235. [CrossRef] [PubMed]

31. Adamič, M.; Jerina, K. Ungulate management in Europe in Slovenia. In European Ungulates and Their Management in the 21st Century; Apollonio, M., Andersen, R., Putman, R., Eds.; Cambridge University Press: Cambridge, UK, 2009 ; pp. 507-527. 
32. Kobayashi, S.; Shimizu, Y.; Yamamoto, T.; Hayama, Y.; Yamaguchi, E.; Hanafusa, Y.; Osaki, M. First nantionwide survey of the seroprevalence of Toxoplasma gondii in wild boars in Japan. Parasitol. Res. 2021, 120, 1505-1509. [CrossRef]

33. Dubey, J.; Rickard, L.; Zimmerman, G.; Mulrooney, D. Seroprevalence of Toxoplasma gondii in llamas (Lama glama) in the northwest USA. Vet. Parasitol. 1992, 44, 295-298. [CrossRef]

34. Antolová, D.; Reiterová, K.; Dubinský, P. Seroprevalence of Toxoplasma gondii in wild boars (Sus scrofa) in the Slovak Republic. Ann. Agric. Environ. Med. 2007, 14, 71-73.

35. Jokelainen, P.; Velström, K.; Lassen, B. Seroprevalence of Toxoplasma gondii in free-ranging wild boars hunted for human consumption in Estonia. Acta Vet. Scand. 2015, 57, 42. [CrossRef] [PubMed]

36. Olsen, A.; Berg, R.; Tagel, M.; Must, K.; Deksne, G.; Enemark, H.L.; Alban, L.; Johansen, M.V.; Nielsen, H.V.; Sandberg, M.; et al. Seroprevalence of Toxoplasma gondii in domestic pigs, sheep, cattle, wild boars, and moose in the Nordic-Baltic region: A systematic review and meta-analysis. Parasite Epidemiol. Control. 2019, 5, e00100. [CrossRef] [PubMed]

37. Bobić, B.; Nikolić, A.; Klun, I.; Djurkovic-Djakovic, O. Kinetics of Toxoplasma infection in the Balkans. Wien. Klin. Wochenschr. 2011, 123, 2-6. [CrossRef] [PubMed]

38. Gazzonis, A.L.; Villa, L.; Riehn, K.; Hamedy, A.; Minazzi, S.; Olivieri, E.; Zanzani, S.A.; Manfredi, M.T. Occurrence of selected zoonotic food-borne parasites and first molecular identification of Alaria alata in wild boars (Sus scrofa) in Italy. Parasitol. Res. 2018, 117, 2207-2215. [CrossRef] 